\title{
OCCURRENCE OF DEEP-SEA SHRIMP Heterocarpus inopinatus TAVARES, 1999 (CRUSTACEA: DECAPODA: CARIDEA) IN POTIGUAR BASIN, NORTHEASTERN BRAZIL
}

\author{
Flávio de Almeida ALVES-JÚNIOR ${ }^{1 *}$; Marina de Sá Leitão Câmara de ARAÚJO²; Jesser Fidelis de \\ SOUZA-FILHO ${ }^{1}$
}

\begin{abstract}
${ }^{1}$ Laboratório de Carcinologia, Museu de Oceanografia, Universidade Federal de Pernambuco, Brasil. E-mail: bioflavio@hotmail.com, jesser fidelis@yahoo.com.br.

*Autor correspondente

${ }^{2}$ Coleção Didática de Zoologia da UPE, Faculdade de Ciências, Educação e Tecnologia de Garanhuns, Universidade de Pernambuco, Brasil. E-mail: mslc.araujo@gmail.com.
\end{abstract}

RESUMO. Heterocarpus inopinatus é um membro da família Pandalidae. É uma espécie endêmica para as águas brasileiras o qual é registrado para os estados da Bahia, Espírito Santo e Rio de Janeiro. Neste trabalho, nós reportamos a ocorrência desta espécie para a Bacia Potiguar no nordeste do Brasil. A Bacia Potiguar está situada no extremo Nordeste do Brasil, entre os estados do Ceará (CE) e Rio Grande do Norte (RN) $\left(03 / 05^{\circ} \mathrm{S} ; 38 / 35^{\circ} \mathrm{W}\right)$. As amostragens foram conduzidas como parte do projeto: Avaliação da Biota Bentônica e Planctônica da Bacia Potiguar e Ceará (Bpot), patrocinado pelo Petróleo Brasileiro S/A (Petrobrás). Na campanha foram analisados 19 indivíduos, sendo 10 fêmeas, 8 machos e 1 juvenil, entre as profundidades de 150-982 m. Portanto, este estudo está aumentando a distribuição geográfica e estendendo a distribuição batimétrica da espécie para profundidades mais rasas na região Nordeste do Brasil, preenchendo as lacunas de distribuição no Atlântico Sul.

Palavras-Chave: Distribuição geográfica, Pandalidae, talude continental, novo registro.

\begin{abstract}
Heterocarpus inopinatus is a member of the family Pandalidae. It is an endemic species from Brazilian' waters which is recorded for states of Bahia, Espírito Santo and Rio de Janeiro. In this paper, we report the occurrence of this species from extreme northeast of Brazil in Potiguar Basin. The Potiguar Basin is situated in the extreme northeast of Brazil, between the states of Ceará (CE) and Rio Grande do Norte (RN) $\left(03 / 05^{\circ} \mathrm{S} ; 38 / 35^{\circ} \mathrm{W}\right)$. Samplings were conducted as part of the project: "Avaliação da Biota Bentônica e Planctônica da Bacia Potiguar e Ceará (Bpot)" sponsored by "Petróleo Brasileiro S/A (Petrobrás)". In the campaign were analyzed 19 individuals, being 10 females, 8 males and 1 juvenile, between the depths of 150-982 $\mathrm{m}$. Therefore, this study is increasing its geographic distribution and thus much extending its bathymetric distribution of the species to shallower depth for the Northeast region of Brazil, filling gaps in the South Atlantic distribution.
\end{abstract}

Keywords: Geographic distribution, Pandalidae, continental slope, new record. 
Alves-Jr. et al., Occurrence of deep-sea shrimp Heterocarpus inopinatus Tavares, 1999 (Crustacea: Decapoda: Caridea) in Potiguar Basin, northeastern Brazil

\section{INTRODUCTION}

The family Pandalidae Haworth, 1825 is represented by 23 genera and 197 species worldwild; in Brazilian waters four genera are known to occur: Pandalus Leach, 1814; Heterocarpus A. Milne-Edwards, 1881; Plesionika Spence Bate, 1888, and Stylopandalus Coutière, 1905 (Ramos-Porto and Coelho, 1998; Tavares, 1999; Cabral et al., 2000; Cardoso and Serejo, 2007; Cardoso, 2009; Rego and Cardoso, 2010). The genus Heterocarpus is usually found in mud substrate from tropical oceans under depths varying from 73 to 2.834 m (Crosnier, 1988; 1999; Tavares, 1999; Chace, 1985).

In Brazilian waters five species have been recorded: Heterocarpus dorsalis Spence Bate, 1888; H. ensifer A. Milne-Edwards, 1881; H. inopinatus Tavares, 1999; H. laevigatus Spence Bate, 1888 and $H$. oryx A. Milne-Edwards, 1881 (Ramos-Porto and Coelho, 1998; Tavares, 1999; Viana et al., 2007; Rego and Cardoso, 2010). This paper reports the geographic distribution of deep-sea shrimp Heterocarpus inopinatus in Potiguar Basin located in the Northeastern of Brazil.

\section{MATERIAL AND METHODS}

The Potiguar Basin is situated in the extreme northeast of Brazil, between the states of Ceará (CE) and Rio Grande do Norte (RN) (03/05 $\left.\mathrm{S} ; 38 / 35^{\circ} \mathrm{W}\right)$ (Alves-Júnior et al., 2016). Samples were collected in two different moments: first on board of the R/V Luke Thomas at station "Arrasto Malha Talude (AR\#)" in 2009, and in a second moment by the R/V Seward Johnson at stations referred to "Malha Talude (MT\#)" in 2011. Both deployments were conducted as part of the project "Avaliação da Biota Bentônica e Planctônica da Bacia Potiguar e Ceará (Bpot)" sponsored by "Petróleo Brasileiro S/A (Petrobrás)". Bottom trawls using net (otter trawl semi-balloon with $50 \mathrm{~mm}$ mesh size and $18 \mathrm{~m}$ of mouth opening) were conducted on the continental slope along isobaths of 389-2068 m. Specimens were preserved in $70 \%$ ethanol for further analysis.

In the laboratory, crustaceans were sorted and identified to species level by observing the diagnostic morphological characters following Tavares (1999), Cardoso and Serejo (2007) and Rego and Cardoso (2010). All material was deposited in the Carcinological Collection of the "Museu de Oceanografia Prof. Petrônio Alves Coelho (MOUFPE)", at Federal University of Pernambuco in Recife, Brazil. Total length $(T L)$ and carapace length $(C L)$ were measured by using a digital caliper $(0.01 \mathrm{~mm})$.

\section{RESULTS}

\section{Systematics.}

Order Decapoda Latreille, 1802

Infraorder Caridea Dana, 1852

Family Pandalidae Haworth, 1825 
Genus Heterocarpus A. Milne-Edwards, 1881

Specie Heterocarpus inopinatus Tavares, 1999

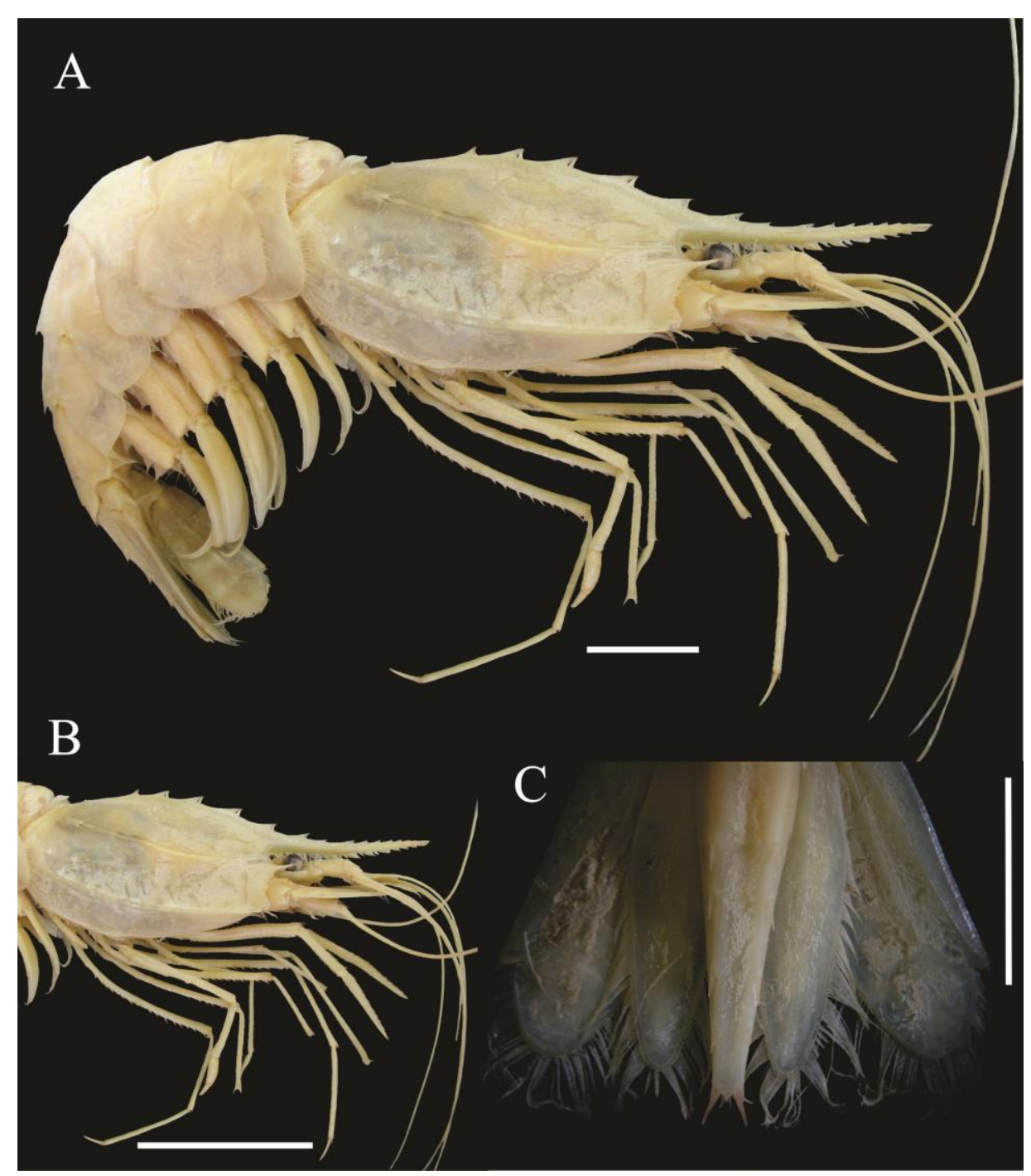

Figure 1. Heterocarpus inopinatus Tavares, 1999, total view (A), carapace view (B) and telson and uropods (C), female (Bpot-Talude \#MT- 71; MOUFPE 15689), from northeastern Brazil. Scale bar $=1 \mathrm{~cm}$

Material examined. 5 individuals, 1 juveniles (TL: $64.2 \mathrm{~mm}$; CL: $14.1 \mathrm{~mm}$ ), 2 Females (TL: 85.8-89.6 mm; CL: 19.2-21.3 mm) and 2 Males (TL: 92.6-98.4 mm; CL: 22.4-25.2 mm), Potiguar Basin, AR\# 55, 04033' S - 036054' W, 150 m, 12 August 2009, MOUFPE: 15.691. 1 Female, (TL: $78.5 \mathrm{~mm}$; CL: $16.4 \mathrm{~mm}$ ), Potiguar Basin, AR\# 51, 04033' S - 036'54' W, 150 m, 20 May 2011, MOUFPE: 17.601. 6 individuals, 2 females (TL: $96.7-98.1 \mathrm{~mm}$; CL: 23.1-23.8 mm)

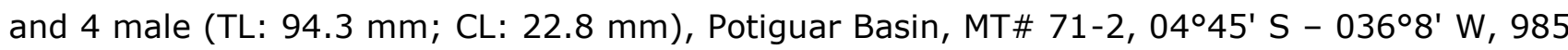
m, 20 May 2011, MOUFPE: 15.694. 3 individuals, 2 Females (TL: 96.8-110.5 mm; CL: 21.6-25.6 $\mathrm{mm}$ ) and 1 Male (TL: $88.4 \mathrm{~mm}$; CL: $21.1 \mathrm{~mm}$ ), Potiguar Basin, MT\# 72, 044ㅇ' S - 036 $23^{\prime} \mathrm{W}$, 969 m, 07 May 2011, MOUFPE: 15.687. 4 individuals, 3 females (TL: 95.4-99.1 mm; CL: 24.4$26.2 \mathrm{~mm}$ ) and 1 male (TL: $98.4 \mathrm{~mm}$; CL: $23.8 \mathrm{~mm}$ ), Potiguar Basin, MT\# 73-2, 04³7' $\mathrm{S}$ 036³0' W, 982 m 16 May 2011, MOUPFE: 15.688. 
Type-locality. Western Atlantic: Brazil, Espírito Santo (19³8'S, 03843'W), 960 m deep.

Distribution. Brazil: Ceará, Rio Grande do Norte, Bahia, Espírito Santo and Rio de Janeiro (Fig. 2). (Tavares, 1999; Cardoso and Serejo, 2007; Serejo et al., 2007; Rego and Cardoso, 2010).

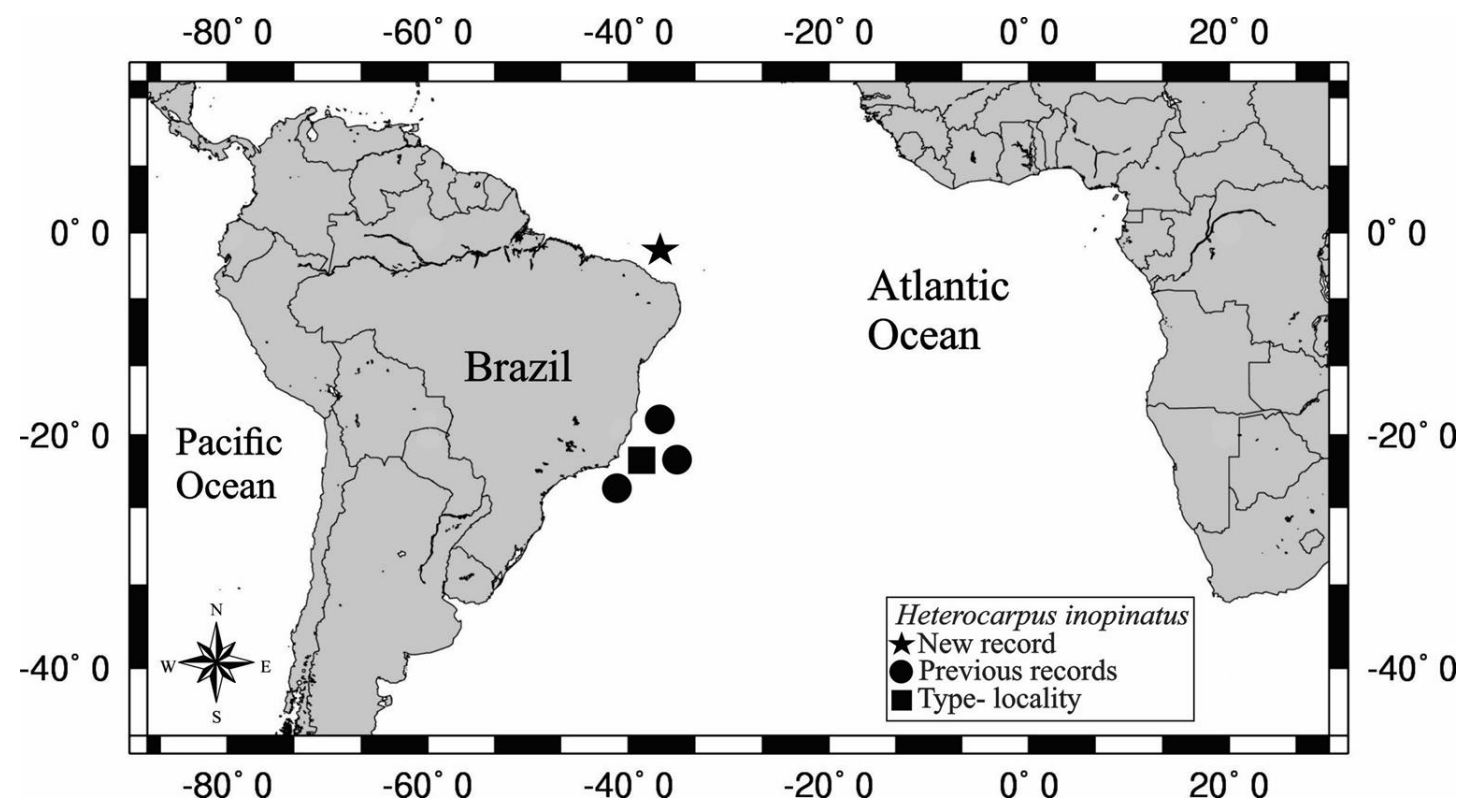

Figure 2. Geographic distribution of Heterocarpus inopinatus Tavares, 1999. Black circles = previous records; star $=$ new record.

Bathymetric Distribution. In Potiguar Basin, the specimens were found between 150-982 m deep, the previous record were between 278-1.718 m (Tavares, 1999; Cardoso and Serejo, 2007; Serejo et al., 2007; Rego and Cardoso, 2010).

\section{DISCUSSION}

The present material does not show many differences when compared with the original species description of Tavares (1999), Cardoso and Serejo (2007), Rego and Cardoso (2010). Specimens from Potiguar Basin show the presence of 4 dorsal spines and 3 pars of terminal spines (Fig. $1, \mathrm{C}$ ), the latter character differs from the original description of $H$. inopinatus, which mentions the occurrence of 2 terminal pairs of spines (Tavares, 1999). However, the presence of 3 pairs of terminal spines has already been reported to $H$. inopinatus found along states of Bahia and Rio de Janeiro (Cardoso and Serejo, 2007; Rego and Cardoso, 2010).

The closest species of $H$. inopinatus also occurring in Brazilian waters is $H$. dorsalis and $H$. oryx. The first can be distinguished from $H$. inopinatus by a dorsal tooth on carapace reaching $2 / 3$ of the carapace while the tooth reaches only $1 / 3$ of carapace in $\mathrm{H}$. dorsalis. On the other hand 
Alves-Jr. et al., Occurrence of deep-sea shrimp Heterocarpus inopinatus Tavares, 1999 (Crustacea: Decapoda: Caridea) in Potiguar Basin, northeastern Brazil

$H$. oryx differs from $H$. inopinatus by the absence of the exopod of the third maxilliped in the first while it is short and distinct in H. inopinatus (Tavares, 1999; Rego and Cardoso, 2010).

Exemplars of the $H$. inopinatus did not abundantly occur along of the continental slope of Potiguar Basin, it was just collected by bottom trawls, but great abundance of this species was collected during Program REVIZEE/Score Central using mid-water and bottom trawls (Rego and Cardoso, 2010). The species of the genus Heterocarpus are benthopelagic, showing nocturnal vertical migrations to the water column, so being more susceptible to be better collected in midwater trawls. The species Heterocarpus inopinatus was previously known to occur on Bahia, Espírito Santo and Rio de Janeiro (Tavares, 1999; Rego and Cardoso, 2010). Therefore, this study is increasing its geographic distribution and thus much extending its bathymetric distribution to shallower depth for the Northeast region of Brazil, filling gaps in the South Atlantic distribution.

\section{ACKNOLEDGEMENTS}

The first author would like to thank CAPES (Coordenação de Aperfeiçoamento de Pessoal de Nível Superior) for the postgraduate scholarship in Oceanography. The authors are also grateful to Petróleo Brasileiro S.A. (Petrobrás) for making the material used in this study available. The authors would like to thank the anonymous reviewers for their precious comments on this paper and Dra. Tatiana Fabricio Maria for the English review and valuable suggestions.

\section{REFERENCES}

Alves-Júnior, F.A., Araújo, M.S.L.C. and Souza-Filho, J.F. (2016), Distribution of two species of Nephropsis Wood-Mason, 1872 (Crustacea, Decapoda, Nephropidae) from northeastern Brazil, Zootaxa, Vol. 4114, pp. 90-94.

Cabral, E., Ramos-Porto, M., Santos, M.C.F., Acioli, F.D., Torres, M.F.A. and Viana, G.F.S. (2000), Shrimps collected in the Northeast of Brazil during the REVIZEE Program (Decapoda: Caridea), Nauplius, Vol. 8, pp. 245-248.

Cardoso, I.A. (2009), Report on some Plesionika Bate, 1888 and the first record of Stylopandalus Coutiére, 1905 (Caridea, Pandalidae) from Brazilian waters, Zootaxa, Vol. 2120, pp. 53-68. Chace, F.A. (1985), The Caridean Shrimps (Crustacea, Decapoda) of the Albatross Philippine Expedition, 1907-1910, Part 3: Families Thalassocarididae and Pandalidae, Smithsonian Contributions to Zoology, Vol. 411, pp. 1-143.

Coutiere, H. (1905), Sur quelques Crustacés provenant des campagnes de la Princesse-Alice (filet à grande ouverture), Comptes Rendus hebdomadaires des Séances de l'Académie des Sciences, Vol. 140, pp. 1113-1115.

Crosnier, A. (1988), Sur les Heterocarpus (Crustacea, Decapoda, Pandalidae) du sud-ouest de I'océan Indien, Remarques sur d'autres espèces ouest-pacifiques du genre et description de 
Alves-Jr. et al., Occurrence of deep-sea shrimp Heterocarpus inopinatus Tavares, 1999 (Crustacea: Decapoda: Caridea) in Potiguar Basin, northeastern Brazil

quatre taxa nouveaux, Bulletin du Muséum national d'Histoire naturelle, Paris, 4 e série, 10, section A, Vol. 1, pp. 57-103.

Crosnier, A. (1999), Un Heterocarpus nouveau (Crustacea, Decapoda, Pandalidae) du Pacifique Sud-Ouest, Zoosystema, Vol. 21, pp. 345-351.

Dana, J.D. (1852), Conspectus of the Crustacea of the Exploring Expedition under Capt. C. Wilkes, U.S.N. Paguridea, continued, Megalopidea and Macroura, The American Journal of Science and Arts, Vol. 14, pp. 116-125.

Haworth, A.H. (1825), A new binary arrangement of the macrurous Crustacea, The Philosophical Magazine and Journal, Vol. 65, pp. 183-184.

Latreille, P.A. (1802), Histoire naturelle, générale et particulière des Crustacés et des Insectes. Ouvrage faisant suite à l'histoire naturelle générale et particulière, composée par Leclerc de Buffon, et rédigée par C.S. Sonnini, membre de plusieurs Sociétés savantes, Dufart, Paris. Vol. 3, 476 p.

Leach, W.E. (1814), Crustaceology, in Routledge, E. (Ed.), Brewster's Edinburgh Encyclopedia, London, Vol. 7, pp. 385-437.

Milne-Edwards, A. (1881), Description de quelques crustacés macroures provenant des grandes profondeurs de la Mer des Antilles, Annales des Sciences Naturelles, Vol. 11, pp. 1-15.

Ramos-Porto, M. and Coelho, P.A. (1998), Malacostraca. Eucarida. Caridea (Alpheoidea excluded), in Young, P.S. (Ed.), Catalogue of Crustacea of Brazil, Rio de Janeiro, Museu Nacional, Série Livros Vol. 6, pp. 325-350.

Rego, A.B.B. and Cardoso, I.A. (2010), Taxonomy and distribution of shrimps genus Heterocarpus A. Milne-Edwards, 1881 collected on the Brazilian slope by the Program REVIZEE - central score, Nauplius, Vol. 18, pp. 117-128.

Serejo, C.S., Young, P.S., Cardoso, I.A., Tavares, C., Rodrigues, C. and Almeida, T.C. (2007) Abundância, diversidade e zonação dos crustáceos no talude da costa central do Brasil $\left(11^{\circ}-22^{\circ} \mathrm{S}\right)$ coletados pelo Programa REVIZEE/Score Central: prospecção pesqueira, in Costa, P.A.S.; Olavo, G. and Martins, A.S. (Ed.), Biodiversidade da fauna marinha profunda na costa central brasileira, Rio de Janeiro, Museu Nacional, Série Livros, Vol. 24, pp. 133162.

Spence Bate, C. (1888), Report on the Crustacea Macrura collected by the Challenger during the years 1873-76, Report on the Scientific Results of the Voyage of H.M.S. "Challenger" during the years 1873-76. Vol. 24, pp. 1-942.

Tavares, M. (1999), New species and new records of deepwater caridean shrimps from the South Atlantic Ocean (Crustacea, Decapoda), Zoosystema, Vol. 21, pp. 671-677.

Viana, G.F.S., Ramos-Porto, M., Torres, M.F.A. and Santos, M.C.F. (2007), Distribution of Heterocarpus laevigatus Bate, 1888 and Plesionika escatilis (Stimpson, 1860) along the Atlantic coast of South America (Crustacea: Caridea: Pandalidae), Zootaxa, Vol. 1577, pp. 33-39. 